\title{
Oxfam's "Behind the Brands" Campaign: How a scorecard ranking, corporate engagement, and consumer activism catalyzed the largest food and beverage companies to change their ways
}

Matthew McFall

Carolyn Rodehau

David Wofford

Follow this and additional works at: https://knowledgecommons.popcouncil.org/departments_sbsr-pgy How does access to this work benefit you? Let us know!

\section{Recommended Citation}

McFall, Matthew, Carolyn Rodehau, and David Wofford. 2017. "Oxfam's 'Behind the Brands' Campaign: How a scorecard ranking, corporate engagement, and consumer activism catalyzed the largest food and beverage companies to change their ways," case study. Washington, DC: Population Council, The Evidence Project. 


\title{
Oxfam's “Behind theBrands"Campaign
}

\author{
How a scorecard ranking, corporate engagement, and consumer activism \\ catalyzed the largest food and beverage companies to change their ways
}

Oxfam launched the "Behind the Brands" campaign in February 2013 to challenge 10 of the largest global food and beverage companies (referred to as the 'Big 10') on their social and environmental policies and practices, and to amplify the voices of key stakeholders such as farmers, communities, consumers and investors calling on the companies to act. These 10 companies were targeted by the campaign because they constitute the most powerful branded actors among food and beverage producers, collectively generating revenues of over $\$ 1$ billion per day and employing millions in their supply chains (Oxfam 2016a). Oxfam looked at the largest overall revenues globally, as well as a company's position in the Forbes 2000 annual ranking, which measures companies based on composite sales, assets, profits, and market value (Oxfam 2014).

"Behind the Brands" illustrates how NGOs balance "carrot" and "stick" approaches to advocating for corporate policy change and how such a strategy can be effective in achieving change. The campaign had both "inside" and "outside" components, with efforts to engage consumers through awareness-raising activities as well as direct communication and collaboration with companies to help them make commitments to improve their environmental and social performance.

The campaign had both "inside" and "outside" components, with efforts to engage consumers through awareness-raising activities, as well as direct communication

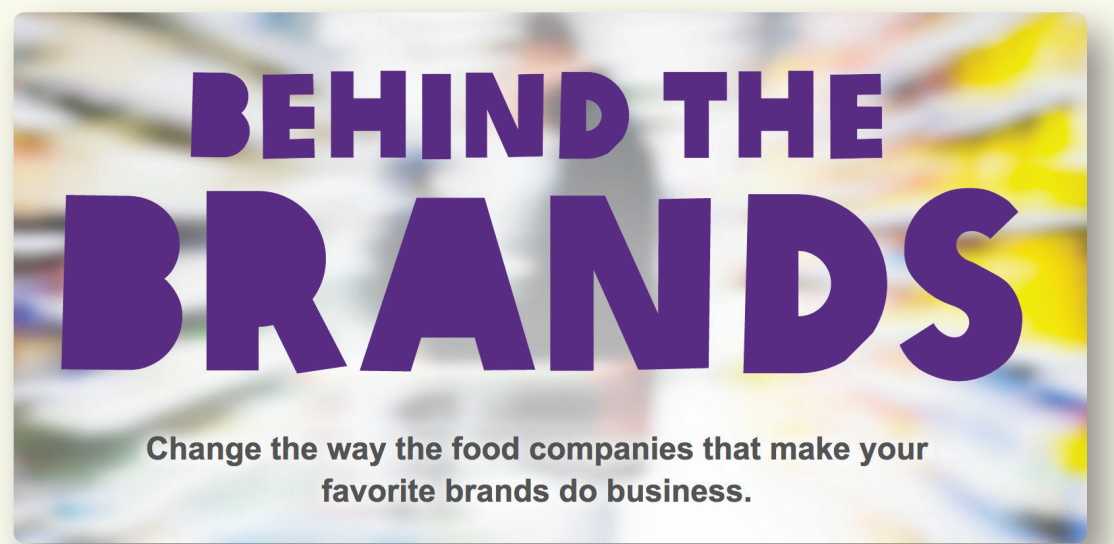
and collaboration with companies to help them make commitments to improve their environmental and social performance. A key component of the campaign was a scorecard, used to initiate a "race to the top" among the 10 companies to improve their scores over the life of the campaign. Oxfam explicitly sought to avoid a "name and shame" style campaign, encouraging consumers

This case study is part of a broader analysis on key lessons women's health advocates can learn from the environmental movement on effective strategies for driving changes in corporate policies and practices. To read the full brief and other case studies, go to http://evidenceproject.popcouncil.org/?p=3034. 

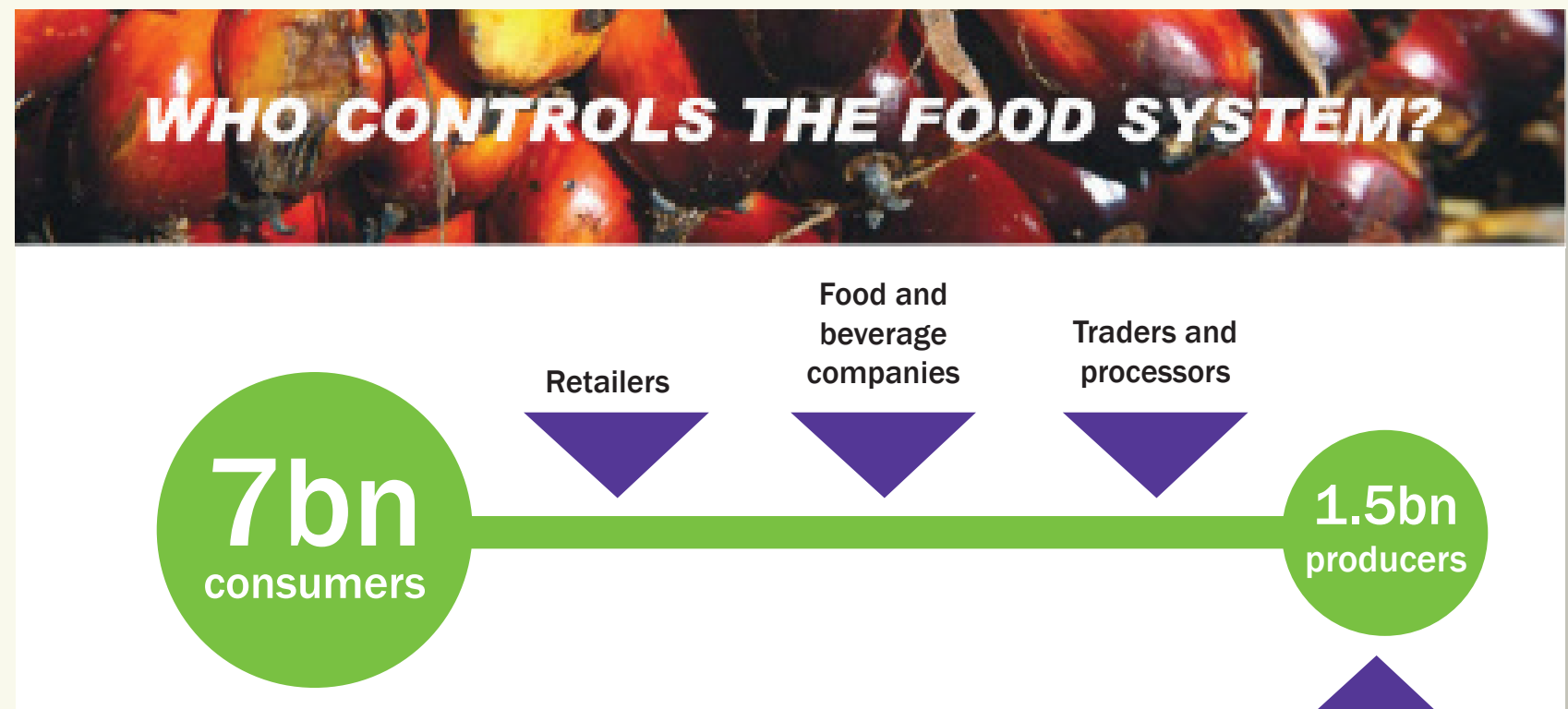

In a world with 7 billion food consumers and 1.5 billion food producers, no more than 500 companies control $70 \%$ of food choice.

Traders and processors

and supporters to actively advocate change by companies rather than suggesting they boycott any products (Kramer 2013). In choosing which companies to target, Oxfam looked at where in the food system it could best leverage its strengths and assets. It focused on companies with visible brands, rather than traders and agribusinesses, since those have less brand recognition among consumers and would therefore not be as influenced by Oxfam's brand and supporter base as the more consumer-facing companies. This type of targeting is reflective of the strategy used nowadays by many major environmental organizations, including World Wildlife Fund, Conservation International, and Greenpeace. Figure 1 illustrates this strategy of targeting "choke points" in the global food system, where most of the food and beverage products are funneled from 1.5 billion producers to 7 billion consumers through a handful of large multinational companies. By targeting these companies, environmental groups can get the most bang for their buck in advocating policy change, with the idea being that these companies will generate the demand among consumers for improved environmental and social performance, which their suppliers will then be required to meet.

The "Behind the Brands" scorecard uses publicly available information on the social and environmental policies of the Big 10 companies, focusing on seven themes (Oxfam 2016a):

1. Land: Inclusive of land rights, access to land, and the sustainable use of it.

2. Women: Primarily women farm workers and small-scale producers in the supply chain of these companies.

3. Farmers: Focused on small-scale farmers growing key commodities.

4. Farm workers: Casual and migrant laborers who work on large farms.

5. Climate Change: Focusing on commitments by these companies to reduce their greenhouse gas emissions, including through avoided deforestation, as well as climate change adaptation for farmers. 
6. Transparency: Focused at the corporate level.

7. Water: Inclusive of water rights, access to water resources, and the sustainable use of those resources.

For each of these themes (except transparency), the scorecard's indicators are grouped into four categories (Oxfam 2016a):

1. Awareness: Does the company demonstrate general awareness of key issues relating to that theme and does it conduct projects to understand and address these key issues?

2. Knowledge: Does the company demonstrate that it measures, assesses and reports key issues, and facts (specifically, in its supply chains) that relate to that theme?

3. Commitments: Does the company commit to addressing the key issues relating to that theme in its supply chains?

4. Supply chain management: Does the company require its suppliers to meet relevant standards related to that theme?

In Oxfam's scorecard methodology, all seven of the above-mentioned themes are weighted equally. Indicators within these themes were developed, where possible, in alignment with widely-accepted best practices, including initiatives like the Carbon Disclosure Project (CDP). Research for the scorecard was completed for Oxfam by the Netherlands-based research and network organization, SOMO (Oxfam 2014).

The "Behind the Brands" campaign has been deemed highly successful by Oxfam and many others, including companies ranked by the scorecard. The campaign generated over 2,500 news stories between January 1 - October 1 of 2014 alone, with a significant presence in both traditional and social media (Griswold 2016). All companies ranked on the scorecard improved their performance over the three-year span of the campaign, with gender equality, land rights, and climate change being the areas which saw the most progress. Oxfam noted that these were the three annual themes covered by the scorecard that year. In particular, anecdotal evidence suggests that suppliers to the Big 10 have changed their practices on gender and land. For example, in Brazil, Coca Cola has engaged their suppliers on land rights as a result of the scorecard, and a majority (eight out of ten) of the Big 10 companies signed the United Nations Women's Empowerment Principles and conducted assessments focusing on the impact of women producers and workers in their supply chains. However, while most companies made improvements on gender equality on the scorecard over the three-year campaign, none achieved a high score in this area (Oxfam 2016a).

There were also indirect benefits from the scorecard and campaign. These enabled Oxfam to convene a multi-stakeholder process with large cocoa companies, traders, cocoa producers' organizations, governments, and NGOs to identify emerging good practice in the cocoa industry for empowering women farmers (Oxfam 2016b). Oxfam also used the "Behind the Brands" campaign and scorecard to engage "Big 10" companies that were not as visible or seemingly progressive - namely Kellogg and General Mills - to commit to important changes in their policies and practices. As a result, Kellogg increased its policy commitments significantly over the three years of the campaign, improving its score dramatically for small-scale farmer support, greenhouse gas emission reductions, and commitment to zero deforestation in its supply chain. 
A combination of company-targeted campaigning, consumer activism, and ongoing engagement efforts by Oxfam's partners and allies contributed to the success of the campaign. Oxfam identified three broad lessons it learned from the campaign (Oxfam 2016a):

1. Consumers care about how companies do business and will take actions that help drive sector-wide policy changes on key sustainability issues.

2. Case studies are effective in demonstrating why companies need to change their policies and practice, by connecting the impact on real farm workers and farmers living in poverty to the actions of their suppliers.

3. Allied investors can help to put pressure on companies to address key issues like climate change and land rights. Investors also share Oxfam's interest in promoting greater transparency and public company reporting.

The "Behind the Brands" campaign brought increased public attention to food and beverage companies and the significant role their supply chains play in social and environmental impacts worldwide, creating pressure on them to make changes. For the past decade, these sectors have garnered increasing attention from the environmental community, but this campaign served to bring wider and more pronounced public attention to the significant impact and influence of these companies (Oxfam 2016a). And while the campaign focused only on 10 companies, the scorecard has helped catalyze policy change and sustainable sourcing commitments more broadly among peer companies, amplifying the message and helping to fuel the "race to the top" that Oxfam intended.

\section{REFERENCES}

Griswold, Belinda. 2016. “Choke Points, Martini Glasses and Bad Guys: Supply Chain Communications Lessons from the Field." Resource Media. http://www.resource-media.org/choke-points-martini-glasses-and-badguys-supply-chain-communications-lessons-from-the-field/. Accessed January 202017.

Kramer, Anna. 2013. “10 everyday food brands-and the few giant companies that own them." http://firstperson.oxfamamerica.org/2013/03/10everyday-food-brands-and-the-few-giant-companies-that-own-them/ Accessed March 302017.

Oxfam. 2013. "Behind the Brands: Food justice and the 'Big 10' food and beverage companies.” https://www.oxfam.org/sites/www.oxfam.org/ files/bp166-behind-the-brands-260213-en.pdf. Accessed March 302017.
Oxfam. 2014. "The Behind the Brands Scorecard Methodology." https:// www.oxfam.org/sites/www.oxfam.org/files/file attachments/btb meth odology document final sept 2014.pdf. Accessed March 302017.

Oxfam. 2016a. "The Journey to Sustainable Food: A three-year update on the Behind the Brands campaign." https://www.oxfam.org/sites/www. oxfam.org/files/file attachments/bp-journey-to-sustainable-food-btb190416-en.pdf. Accessed March 302017.

Oxfam. 2016b. “Women's Rights in the Cocoa Sector: Examples of Emerging Good Practice.” http://oxf.am/Zh24. Accessed March 302017.

\section{THE EVIDENCE PROJECT}

Population Council 4301 Connecticut Avenue NW Suite 280

Washington, DC 20008 USA tel +12022379400 evidenceproject@popcouncil.org

(3) USAID

The Evidence Project is made possible by the generous support of the American people through the United States Agency for International Development (USAID) under the terms of cooperative agreement no. AID-OAA-A-13-00087. The contents of this document are the sole responsibility of the Evidence Project and Population Council and do not necessarily reflect the views of USAID or the United States Government.

\section{Evidence}

The Evidence Project uses implementation science-the strategic generation, translation, and use of evidence-to strengthen and scale up family planning and reproductive health programs to reduce unintended pregnancies worldwide. The Evidence Project is led by the Population Council in partnership with INDEPTH Network, International Planned Parenthood Federation, PATH, Population Reference Bureau, and a University Research Network.

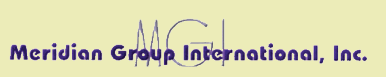

Meridian Group International, Inc. is a woman-owned, small business that works with the private and public sectors to create innovative programs and partnerships that benefit both business and society. Meridian Group International, Inc. is a partner of the Evidence Project and the Cambodia Worker Health Coalition.

Suggested Citation: McFall, Matthew, Carolyn Rodehau, and David Wofford. 2017. “Oxfam's "Behind the Brands" Campaign,” Case Study. Washington, DC: Population Council, The Evidence Project.

(C) 2017 The Population Council, Inc. 